\title{
Investigation on Ethylenediaminetetra-Acetic Acid as Corrosion Inhibitor for Mild Steel in 1.0M Hydrochloric Acid
}

\author{
Ahmed Y. Musa (Corresponding author) \\ Department of Chemical and Process Engineering \\ Universiti Kebangsaan Malaysia, Bangi, 43600, Selangor, Malaysia \\ Tel: 60-17-308-6840 E-mail: ahmed.musa@ymail.com \\ Abdul Amir H. kadhum \\ Department of Chemical and Process Engineering \\ Universiti Kebangsaan Malaysia, Bangi, 43600, Selangor, Malaysia \\ Tel: 60-3-8921-6411 E-mail: amir@eng.ukm.my \\ Mohd Sobri Takriff \\ Department of Chemical and Process Engineering \\ Universiti Kebangsaan Malaysia, Bangi, 43600, Selangor, Malaysia \\ Tel: 60-3-8921-6400 E-mail: sobri@eng.ukm.my \\ Abdul Razak Daud \\ School of Applied Physics \\ Universiti Kebangsaan Malaysia, Bangi, 43600, Selangor, Malaysia \\ Tel: 60-3-8921-3806 E-mail:kpfg@ukm.my \\ Siti Kartom Kamarudin \\ Department of Chemical and Process Engineering \\ Universiti Kebangsaan Malaysia, Bangi, 43600, Selangor, Malaysia \\ Tel: 60-3-8921-6422 E-mail: ctie@eng.ukm.my
}

The research is financed by National University of Malaysia. No.UKM GUP-BTT-07-25-170

\begin{abstract}
The influence of ethylenediaminetetra-acetic acid (EDTA) on the corrosion of mild steel in 1.0 M hydrochloric acid solution was investigated by means of potentiodynamic polarization and electrochemical impedance spectroscopy (EIS). The efficiency of EDTA was compared with thiourea. Primary results obtained revealed that EDTA performed as good corrosion inhibitor for mild steel in $1.0 \mathrm{M}$ hydrochloric acid media comparing with thiourea. Polarization curves show that the behavior of EDTA and thiourea are mixed-type inhibitors. EIS shows that the control step for corrosion process is a charge transfer mechanism.
\end{abstract}

Keywords: Corrosion inhibitor, Ethylenediaminetetra-acetic acid, Thiourea, Mild steel, Electrochemical measurement

\section{Introduction}

Mild steel is widely used as a constitutional material in many industries due to its good mechanical properties and low cost. The corrosion of mild steel is of fundamental academic and industrial concern that has received a considerable amount of attention. Acid pickling baths are employed to remove undesirable scale from the surface of the metals. Once the scale is removed, the acid is then free for further attack on the metal surface. The use of inhibitor is one of the most practical methods for protection against corrosion, especially in acidic media.

A survey of literature reveals that the applicability of organic compounds as corrosion inhibitors for mild steel in acidic media has been recognized for a long time. Compounds studied as inhibitors include triazole derivatives (Bentiss et al 1999a , Bentiss et al 1999b), bipyrazolic derivatives (Touhami et al 2000), surfactants (Algaber et al 2004, Branzoi et al 2000) aromatic hydrazides (Quraishi et al 2001) , organic dyes (Oguzie et al 2004a, Oguzie et al 2005b) , Poly 
(4-vinylpyridine) ( Larabi et al 2004) and thiosemicarbazide-type organic compounds (Benali 2006). These compounds can adsorb on the mild steel surface and block the active sites decreasing the corrosion rate.

This paper describes the affect of ethylenediaminetetra-Acetic acid (EDTA), $\mathrm{C}_{10} \mathrm{H}_{16} \mathrm{~N}_{2} \mathrm{O}_{8} \mathrm{Na}_{2}$, on corrosion inhibition of mild steel in $1.0 \mathrm{M}$ hydrochloric acid solutions comparing with thiourea. Figure 1 shows the molecular structure of used inhibitors.

\section{Experimental}

Commercially mild steel metal was used. Sample was mechanically polished using $\mathrm{SiC}$ paper in successive grades from 200 to 1500 and was rinsed with methanol. The acid solutions were made from RA grade $\mathrm{HCl}$. Appropriate concentration of acid was prepared by using distilled water. The measurements were carried out in a three electrodes electrochemical cell with a graphite counter electrode and saturated calomel electrode (SCE) as reference. Potentiodynamic polarization curves were obtained starting from Ecorr with the potential scan rate of $125 \mu \mathrm{V} / \mathrm{s}$. EIS measurement was carried out on steady state open circuit potential (OCP) disturbed with amplitude of $10 \mathrm{mV}$ A.C. sine wave at frequencies between 0.01 $\mathrm{Hz}$ and $100 \mathrm{KHz}$. Measurements were performed at room temperature using Potentiostat/Galvanostat/ZRA (Gamery instrument, Ref600 model, USA)

\section{Results and Discussion}

\subsection{Polarization measurements}

The effect of the concentration of EDTA and thiourea are shown in Figure 2 which presents the anodic and cathodic Tafel curves of mild steel in $1 \mathrm{M} \mathrm{HCl}$. Values of anodic $\beta a$ and cathodic $\beta c$ Tafel constant and corrosion current density are listed in Table 1 and 2. These values were calculated from the intersection of the anodic and cathodic Tafel lines of the polarization curve at Ecorr. The inhibition efficiencies are calculated by the following expression:

$$
I E \%=\frac{i_{\text {unhibit }}-i_{\text {inhibir }}}{i_{\text {unhibi: }}} \times 100
$$

where $i_{\text {unhibit }}$ and $i_{\text {inhibit }}$ are respectively, the corrosion current density without and with EDTA or thiourea in $1.0 \mathrm{M} \mathrm{HCl}$ solution.

The anodic and cathodic Tafel lines for mild steel in presence of EDTA or thiourea were almost parallel upon increasing inhibitor concentrations. This suggests that the inhibitor act by simple blocking the mild steel surface (Manahan, 1996). In the other words, the inhibitor decreasing the exposed surface area for corrosion as well as it doesn't affect the mechanism of mild steel dissolution or hydrogen evolution reaction. Only when the change in Ecorr value is no less than $85 \mathrm{mV}$, a compound can be recognized as an anodic or a cathodic type inhibitor (Ashassi-Sorkhabi et al 2004). The largest displacement of the corrosion potentials (E) were about $8 \mathrm{mV}$ and $11 \mathrm{mV}$ in presence of EDTA and thiourea, respectively. Therefore, EDTA and thiourea are acts as corrosion mixed-type inhibitors. Also the inhibition efficiencies increase with increasing inhibitors concentration as shown in Table 1 and 2.

\subsection{EIS measurements}

The results of EIS were figured by Nyquist plots, Figure 3. Double layer capacitance values $(C d l)$ and polarization resistance values $(R p)$ were obtained from impedance as described by Moretti (2004). The fitted values of $R p$ and $C d l$ are listed in Table 1 and 2 . The inhibition efficiencies IE\% is calculated by polarization resistance $(R p)$ as follows:

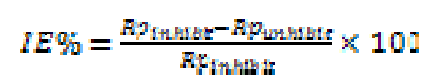

The $R p$ values increase with the increase in concentration of either EDTA or thiourea, indicating an insulated adsorption layer formation; the decrease in $C d l$ values suggested a decrease in local dielectric constant between the metal and electrolyte induced by the adsorption of EDTA or thiourea (Khaled and Hackerman 2003).

\section{Conclusion}

EDTA showed good inhibition performance comparing with thiourea. Polarization curves indicated that the EDTA and thiourea behave mainly as mixed-type inhibitors. EIS showed that the charge transfer controls the corrosion process in the uninhibited and inhibited solutions either for EDTA or thiourea.

\section{Acknowledgment}

This work was supported by National University of Malaysia (No. UKM GUP-BTT-07-25-170) which is gratefully acknowledged. 


\section{References}

Algaber AS, EM. El-Nemna, \& Saleh MM. (2004). Effect of octylphenol polyethylene oxide on the corrosion inhibition of steel in 0.5 $\mathrm{M} \mathrm{H}_{2} \mathrm{SO}_{4}$. Journal of Materials Chemistry and Physics, 86, 26-32.

Ashassi-Sorkhabi H, MR. Majidi, \& Seyyedi K. (2004). Investigation of inhibition effect of some amino acids against steel corrosion in $\mathrm{HCl}$ solution. Journal of Applied Surface Science, 225, 176-185.

Benali O, L. Larabi, S.M Mekelleche, \& Harek Y. (2006). Influence of substitution of phenyl group by naphthyl in a diphenylthiourea molecule on corrosion inhibition of cold-rolled steel in $0.5 \mathrm{M} \mathrm{H}_{2} \mathrm{SO}_{4}$. Journal of Material Science, 41 , 7064-7073.

Bentiss F, M .Traisnel, L. Gengembre and .Lagrene' e. M. (1999a). A new triazole derivative as inhibitor of the acid corrosion of mild steel: electrochemical studies, weight loss determination, SEM and XPS. Journal of Applied Surface Science, 152, 237-249.

Bentiss F, M. Lagrene ' e, M. Traisnel, \& Gornez J. (1999b). The corrosion inhibition of mild steel in acidic media by a new triazole derivative. Journal of Corrosion Science, 41, 789-803.

Branzoi V, F. Branzoi, \& Baibarac M. (2000). The inhibition of the corrosion of armco iron in $\mathrm{HCl}$ solutions in the presence of surfactants of the type of n-alkyl quaternary ammonium salts. Journal of Materials Chemistry and Physics, 65 , 288-297.

Khaled KF, \& Hackerman N. (2004). Investigation of the inhibitive effect of ortho-substituted anilines on corrosion of iron in $0.5 \mathrm{M} \mathrm{H}_{2} \mathrm{SO}_{4}$ solutions. Journal of Materials Chemistry and Physics, 82, 949-960.

Larabi L, Y. Harek, M. Traisnel, \& Mansri A. (2004). Synergistic influence of poly(4-vinylpyridine) and potassium iodide on inhibition of corrosion of mild steel in $1 \mathrm{M} \mathrm{HCl}$. Journal of Applied Electrochemistry, 34,833-889.

Manahan SE. (1996). Environmental Chemistry. sixth ed. Lewis Publishers, (Chapter 6).

Moretti, G., Guidi, F., and Grion, G. (2004), Tryptamine as a green iron corrosion inhibitor in 0.5 M deaerated sulphuric acid, Corrosion science, 46, 387-403.

Oguzie EE, C. Unaegbu, CBN. Okolue, \& Onuchukwu AI. (2004a). Inhibition of mild steel corrosion in sulphuric acid using indigo dye and synergistic halide additives. Journal of Materials Chemistry and Physics, 84,363-368.

Oguzie EE, GN. Onuoha, \& Onuchukwu AI. (2005b). Inhibitory mechanism of mild steel corrosion in 2 M sulphuric acid solution by methylene blue dye. Journal of Materials Chemistry and Physics, 89, 305-311.

Quraishi MA, R. Sardar, \& Jamel D. (2001). Corrosion inhibition of mild steel in hydrochloric acid by some aromatic hydrazides. Journal of Materials Chemistry and Physics, 71, 309-313.

Touhami T, A. Aounti, Y. Abed, B. Hammouti, S. Kertit, A. Ramdani, \& K. Elkacemi. (2000). Corrosion Inhibition of Armco Iron In $1 \mathrm{M} \mathrm{Hcl} \mathrm{Media} \mathrm{By} \mathrm{New} \mathrm{Bipyrazolic} \mathrm{Derivatives.} \mathrm{Corrosion} \mathrm{Science,} \mathrm{42,} \mathrm{929-94.}$

Table 1. Polarization parameters and EIS parameters for mild steel in 1.0 M HCl with different concentrations of EDTA

\begin{tabular}{|l|l|l|l|l|l|l|l|}
\hline Technique & Parameters & \multicolumn{5}{|c|}{ Inhibitor concentration (mg/l) } \\
\hline & & Blank & 10 & 20 & 40 & 80 & 160 \\
\hline Polarization parameters & Ecorr $(\mathrm{mV})$ & 493 & 497 & 500 & 499 & 503 & 495 \\
\hline & Icorr $\left(\mu \mathrm{A} / \mathrm{cm}^{2}\right)$ & 615 & 452 & 356 & 334 & 289 & 192 \\
\hline & $\beta \mathrm{a}(\mathrm{mV} /$ decade $)$ & 0.12 & 0.16 & 0.11 & 0.1 & 0.1 & 0.1 \\
\hline & $\beta \mathrm{c}(\mathrm{mV} /$ decade $)$ & 0.14 & 0.17 & 0.13 & 0.13 & 0.13 & 0.12 \\
\hline & $\mathrm{IE} \%$ & 0 & 26.50 & 42.11 & 45.69 & 53.01 & 68.78 \\
\hline EIS parameters & $\mathrm{Rp}\left(\mathrm{ohm} . \mathrm{cm}^{2}\right)$ & 36.5 & 48.06 & 49.23 & 54.15 & 55.02 & 68 \\
\hline & $\mathrm{Cdl}\left(\mu \mathrm{F} / \mathrm{cm}^{2}\right)$ & 173.9 & 137.6 & 127.7 & 113.1 & 111.9 & 89.5 \\
\hline & $\mathrm{IE} \%$ & 0 & 24.05 & 25.86 & 32.59 & 33.66 & 46.32 \\
\hline
\end{tabular}


Table 2. Polarization parameters and EIS parameters for mild steel in $1.0 \mathrm{M} \mathrm{HCl}$ with different concentrations of thiourea

\begin{tabular}{|l|l|l|l|l|l|l|l|}
\hline Technique & Parameters & \multicolumn{6}{|c|}{ Inhibitor concentration $(\mathrm{mg} / \mathrm{l})$} \\
\hline & & Blank & 10 & 20 & 40 & 80 & 160 \\
\hline Polarization parameters & Ecorr $(\mathrm{mV})$ & 493 & 510 & 512 & 507 & 514 & 513 \\
\hline & Icorr $\left(\mu \mathrm{A} / \mathrm{cm}^{2}\right)$ & 615 & 504 & 431 & 371 & 298 & 234 \\
\hline & $\beta \mathrm{a}(\mathrm{mV} /$ decade $)$ & 0.12 & 0.11 & 0.10 & 0.11 & 0.10 & 0.12 \\
\hline & $\beta \mathrm{c}(\mathrm{mV} /$ decade $)$ & 0.14 & 0.13 & 0.13 & 0.13 & 0.12 & 0.13 \\
\hline & $\mathrm{IE} \%$ & 0.00 & 18.05 & 29.92 & 39.67 & 51.54 & 61.95 \\
\hline EIS parameters & $\mathrm{Rp}\left(\mathrm{ohm} . \mathrm{cm}^{2}\right)$ & 36.5 & 68.27 & 73.64 & 84.64 & 86.59 & 95.55 \\
\hline & $\mathrm{Cdl}\left(\mu \mathrm{F} / \mathrm{cm}^{2}\right)$ & 173.9 & 147.4 & 135,2 & 127.2 & 114.5 & 85.4 \\
\hline & $\mathrm{IE} \%$ & 0 & 46.53 & 50.43 & 56.87 & 57.84 & 61.8 \\
\hline
\end{tabular}<smiles>O=C(O)CN(CCN(CC(=O)O)CC(=O)O)CC(=O)O</smiles><smiles>NC(N)=S</smiles>

b

Figure 1. Molecular structures for EDTA (a) and thiourea (b)

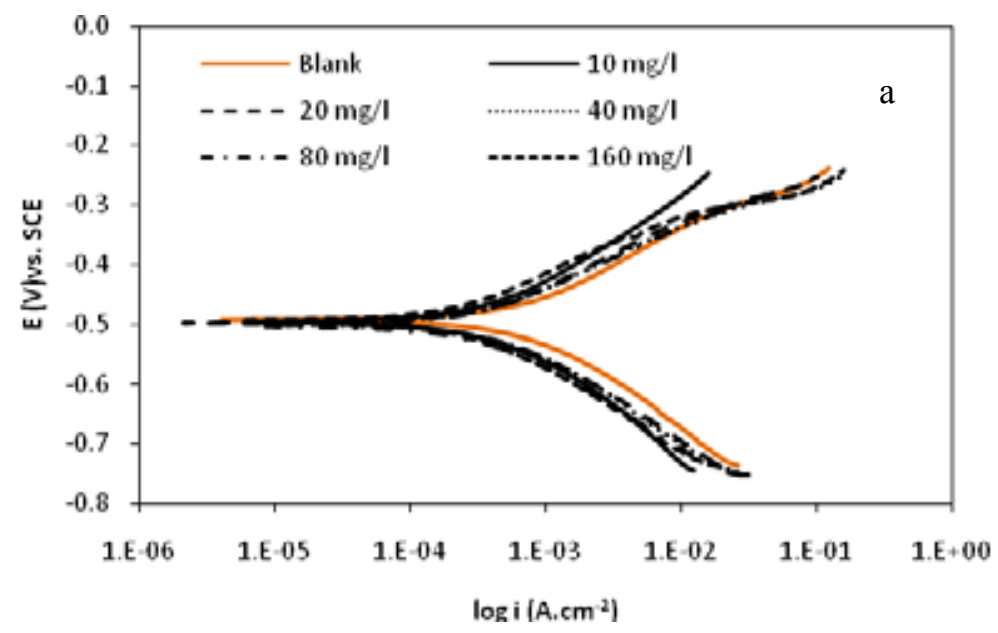




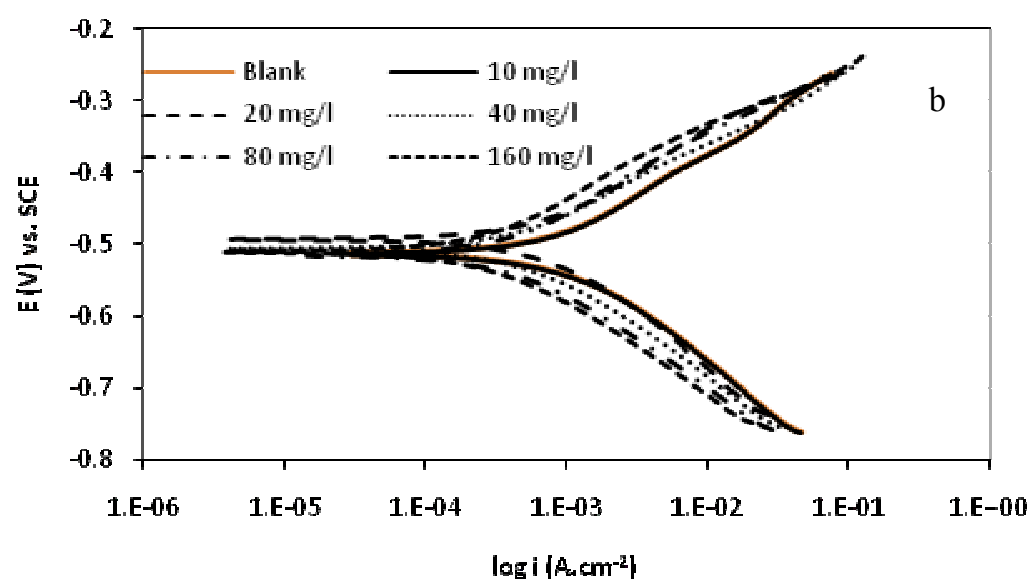

Figure 2. Polarization curves for mild steel in $1.0 \mathrm{M} \mathrm{HCl}$ with different concentrations of EDTA (a) and thiourea (b)
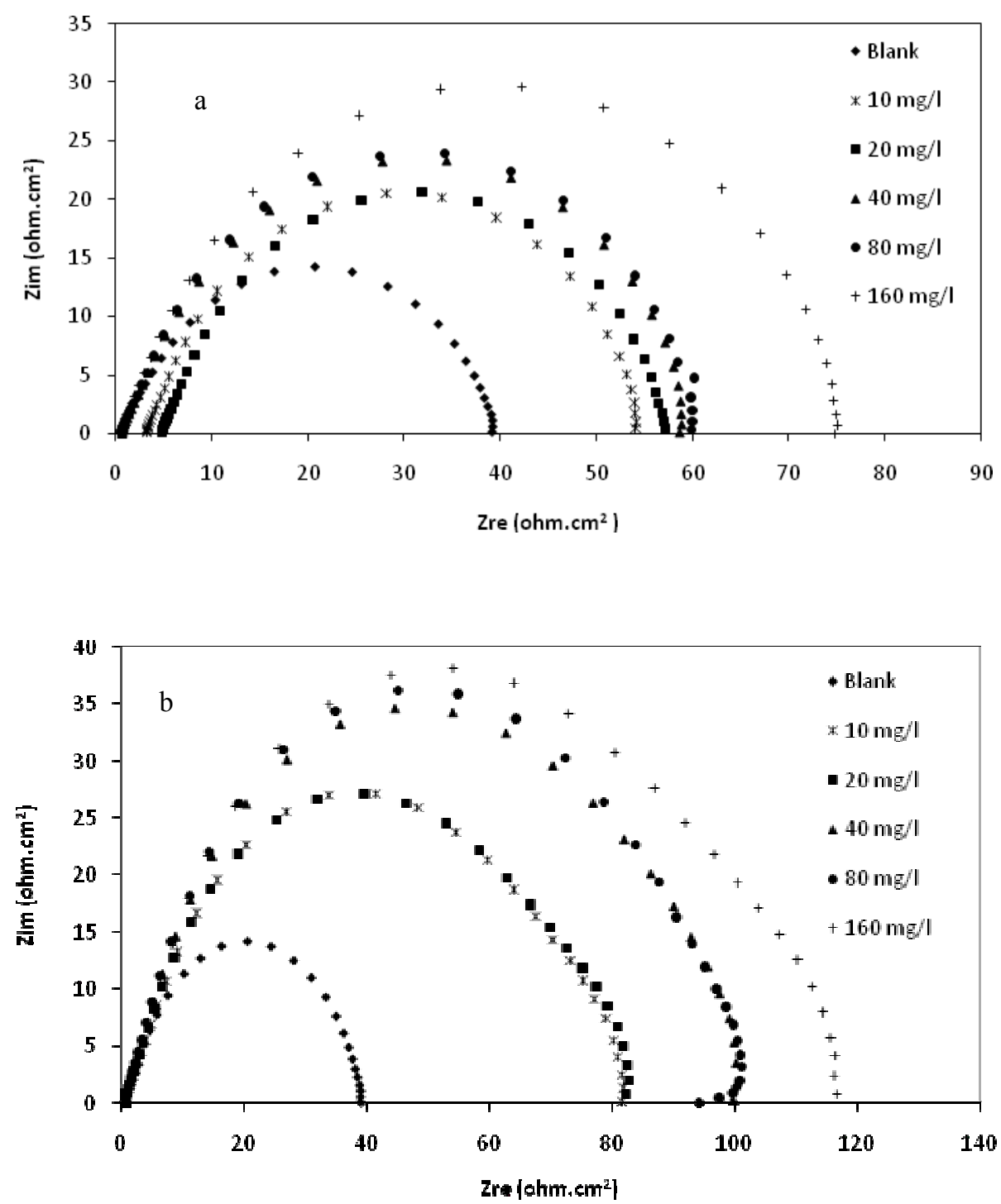

Figure 3. Nyquist plots for mild steel in $1.0 \mathrm{M} \mathrm{HCl}$ with different concentrations of EDTA (a) and thiourea(b) 